\title{
FIRES IN THE DARK. WOOD AND CHARCOAL ANALYSIS OF THE EARLY MEDIEVAL FUNERARY DEPOSITS IN THE CAVE OF RIOCUEVA (CANTABRIA, SPAIN)
}

\author{
ENRIQUE GUTIÉRREZ-CUENCA ${ }^{(1)}$, JOSÉ ÁNGEL HIERRO-GÁRATE ${ }^{(1)}$, INÉS L. LÓPEZ-DÓRIGA ${ }^{(2)}$ \& MARÍA \\ MARTÍN-SEIJO ${ }^{(3)}$
}

Abstract:

\begin{abstract}
The results of the uncharred wood and charcoal analysis carried out on samples from the site are presented in this work. The assemblages comprised debris from combustion structures, remains related to the funerary burnings and torches, and also fragments of uncharred wood probably related to the funerary rite. The cave of Riocueva was used as a burial place at some point between the 7th and 8th centuries cal. AD. Archaeological work carried out between 2010 and 2014 has recovered the remains of at least eight young individuals and many associated objects: glass beads, rings, spindle hooks, knives and pot sherds, among others. As in other burial caves of similar chronologies from the Cantabrian region, rituals linked to the treatment of corpses have been detected. The destruction and burning of the skulls is the most stunning of them. Furthermore, burning grain beside the bodies, a custom forbidden by medieval penance books, has been tentatively suggested as a possible practice forming part of the rituals.
\end{abstract}

Keywords: Funerary Archaeology, Burned bones, Archaeobotany, Fire, Ritual

Resumen: $\quad$ Fuegos en la oscuridad. Análisis xilo-antracológico de los depósitos sepulcrales altomedievales de Riocueva (Cantabria, España)

Los resultados de los análisis xilo-antracológicos llevados a cabo en las muestras de este yacimiento se presentan en este trabajo. Las muestras incluyen restos relacionados con estructuras de combustión, residuos de las quemas funerarias y de las antorchas, así como fragmentos de madera no quemada asociados probablemente al rito funerario. La cueva de Riocueva fue utilizada como lugar de enterramiento en algún momento durante el período comprendido entre los siglos VII y VIII cal. DC. El trabajo arqueológico llevado a cabo entre los años 2010 y 2014 ha proporcionado los restos de al menos ocho individuos jóvenes y muchos objetos asociados a los mismos: cuentas de vidrio, anillos, ganchos de huso, cuchillos y fragmentos cerámicos entre otros. Como sucede en otras cuevas sepulcrales de cronologías similares en Cantabria, se han detectado rituales relacionados con el tratamiento de los cuerpos. La destrucción y quema de los cráneos es la más impresionante de ellas. Además, la quema de grano al lado de los cuerpos, una costumbre prohibida en los libros de penitencia medievales, ha sido también sugerida como una posible práctica.

Palabras clave: Arqueología funeraria, Huesos quemados, Arqueobotánica, Fuego, Ritual

\section{INTRODUCTION}

This paper presents the results of uncharred wood and charcoal analysis from samples recovered at the cave of Riocueva (Entrambasaguas) in the Cantabrian region (Northern Spain). Archaeological surveys have been carried out in this cave between 2010 and 2014 within the framework of the Mauranus research project (GUTIÉRREZ CUENCA \& Hierro GÁRATe, 2014; GutiérRez CUENCA \& HIERRO GÁRATE, 2016). The earliest archaeological works on the site were undertook in the 1950s, when some finds dated to the Palaeolithic, Late Prehistoric and Visigothic periods were retrieved from the outer part of the cave (PENIIL \& RUIZ 1971). In the early 1980s, the CAEAP group found many potsherds on the surface of the Galería del Campamento. The pottery was initially ascribed to the Iron Age (MORLOTE et al. 1996) but a Visigothic chronology (6th-8th centuries AD) was later suggested (HIERRO-GÁRATE 2002). The cave of
Riocueva belongs to a karstic system over $3 \mathrm{~km}$ long (Fig. 1). The cave has a small entrance and chamber that leads into a low crawling passage which ends in the gallery known as "Galería del Campamento". Early medieval archaeological remains are spread along the first half of this gallery, about $60 \mathrm{~m}$ long, due to the existence of post-depositional disturbances -mainly animal burrowing-. The complete absence of sunlight and high levels of humidity make it unsuitable to be used as shelter.

A funerary deposit dated to the 7th8th centuries has been identified ${ }^{1}$. Five human bones, two charred grains and one potsherd have been dated by radiocarbon and thermoluminiscence (Table 1 and 2), providing internally consistent results around the 7th-8th centuries AD. Due to the deviation inherent to the radiometric dates of this period, it is currently very difficult to conclude whether all the remains belong to a single funerary event or, on the contrary, correspond to isolated

${ }^{(1)}$ Proyecto Mauranus. Corresponding author: Enrique Gutiérrez Cuenca. Proyecto Mauranus. egcuenca@gmail.com

${ }^{(2)}$ Wessex Archaeology, Portway House, Old Sarum Park, Salisbury SP4 6EB, United Kingdom

${ }^{(3)}$ Grupo de Estudos para a Prehistoria do NW Ibérico-Arqueoloxía, Antigüidade e Territorio. GEPN-AAT (GI-1534). Departamento de Historia. Universidade de

Santiago de Compostela. Praza da Universidade 1. 15782. Santiago de Compostela, Spain

${ }^{1}$ These deposits have been previously described in GuTIÉRrez CuENCA \& HIERRo GÁrate 2014 and Gutiérrez CuENCA \& Hierro GÁrate 2016. 
burial episodes separated by lapses of years or even decades. In addition, an unidentified wood charcoal fragment from a fireplace has provided a radiocarbon dating result on the 2 nd to 4 th century cal $\mathrm{AD}$ (Table 1), which notably differs from the other seven. This fact points either to another previous - and non sepulchral - usage of the inner part of the cave in Roman times, or to an old-wood effect, due to dating charcoal from potentially long-lived taxa. In order to test these hypotheses, another wood charcoal sample of Fagus sylvatica from the same test pit has been sent for radiocarbon dating.

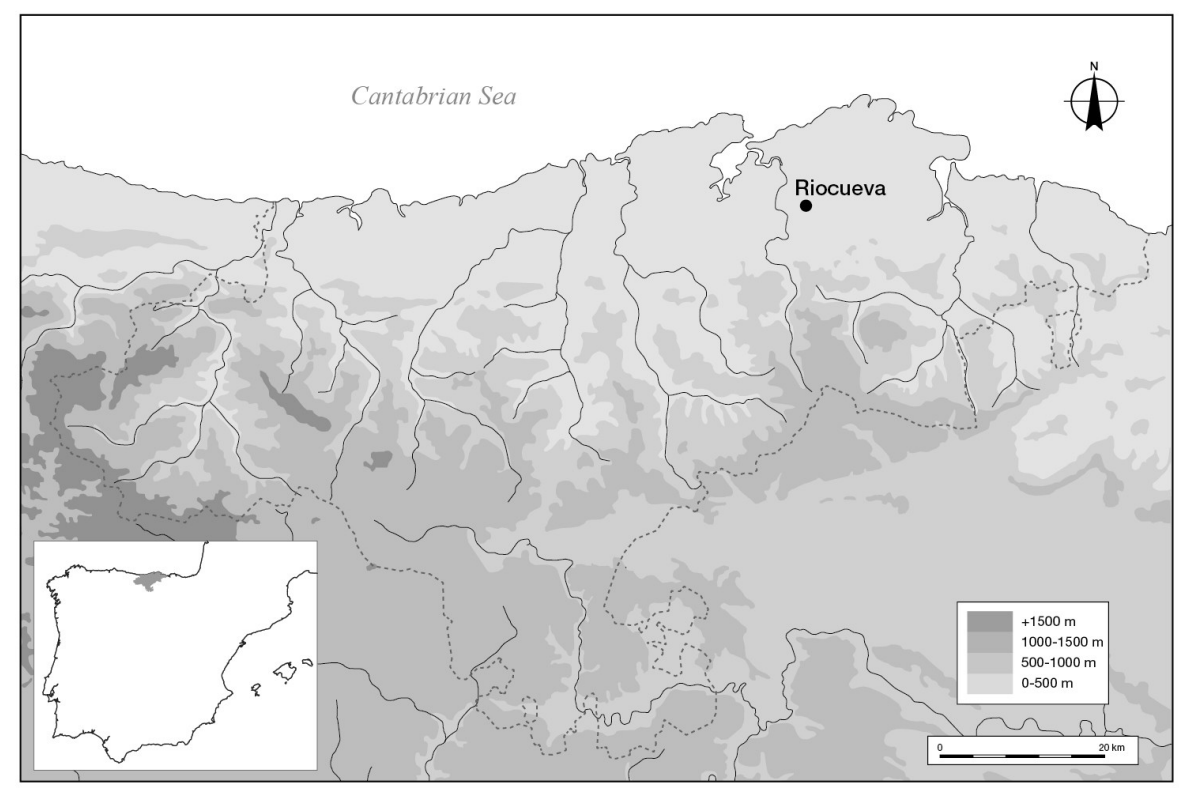

Fig. 1. Location of Riocueva (Entrambasaguas, Cantabria).

Fig. 1. Localización de Riocueva (Entrambasaguas, Cantabria).

Table 1. Radiocarbon dating results from Riocueva calibrated using Oxcal 4.2 (curve IntCal13) (REIMER et al. 2013).

Tabla 1. Resultados de las dataciones radiocarbónicas de Riocueva calibradas usando Oxcal 4.2 (curva IntCal13) (REIMER et al. 2013).

\begin{tabular}{|c|c|c|c|c|}
\hline Sample Code & $\begin{array}{c}\text { Conventional } \\
\text { radiocarbon age (BP) }\end{array}$ & $\begin{array}{c}\text { 2 Sigma calibrated } \\
\text { result (AD) }\end{array}$ & Material & References \\
\hline Poz-39142 & $1380 \pm 30$ & $606-681$ & Human bone & $\begin{array}{c}\text { GUTIÉRREZ-CUENCA \& HIERRO- } \\
\text { GÁRATE, 2010-12 }\end{array}$ \\
\hline Poz-46496 & $1265 \pm 30$ & $666-683$ & Human bone & GUTIÉRREZ-CUENCA et al. 2014 \\
\hline Poz-46497 & $1305 \pm 30$ & $658-796$ & Human bone & GUTIÉRREZ-CUENCA et al. 2014 \\
\hline Poz-49634 & $1300 \pm 30$ & $660-770$ & Cereal grain & GUTIÉRREZ-CUENCA et al. 2014 \\
\hline Poz-59617 & $1760 \pm 30$ & $171-383$ & Charcoal & Unpublished \\
\hline Poz-59618 & $1210 \pm 30$ & $694-892$ & Cereal grain & Unpublished \\
\hline Poz-59619 & $1285 \pm 30$ & $666-771$ & Human bone & Unpublished \\
\hline Poz-59620 & $1255 \pm 30$ & $672-868$ & Human bone & Unpublished \\
\hline
\end{tabular}

Table 2. Termoluminiscence date from Riocueva.

Tabla 2. Fecha de termoluminiscencia de Riocueva.

\begin{tabular}{|c|c|c|c|c|}
\hline Sample Code & Age BP & Result AD & Material & Reference \\
\hline $\begin{array}{c}\text { MaDN- } \\
6061 . \mathrm{BIN}\end{array}$ & $1345 \pm 77$ & $532-800$ & Potsherd & $\begin{array}{c}\text { GUTIÉRREZ-CUENCA \& HIERRO- } \\
\text { GÁRATE, 2010-12 }\end{array}$ \\
\hline
\end{tabular}


The study of the assemblages of uncharred wood and charcoal is crucial to understand past activities developed in this cave, as they are most probably directly related: the charcoal to the fires and the non-carbonised wood to other parts of the funerary rites. The archaeobotanical analysis focused on the assemblages of wood and charcoal remains with the aim of reaching a botanical identification and recording their dendrological and taphonomical attributes. These elements and the analysis of their spatial distribution and association with other archaeological remains have also been examined.

\section{FUNERARY AND POST-SEPULCHRAL PRACTICES}

\subsection{Human remains}

The human remains correspond to at least 8 young individuals: a perinatal, 3 children (between 2 and 3, between 3 and 4 and between 6 and 11 years old each); an individual between 12 and 18 years old and 3 young adults $(<35 \text { years old })^{2}$. The finds associated to these human remains included ceramic sherds from several cooking pots, fragments of an iron cauldron plated with a copper alloy, the foot of a glass cup, spindle hooks, knives, a fishhook and items of personal adornment, such as a copper buckle tongue with a shield-shaped base, a bronze chain with $\mathrm{S}$ shaped links, iron shoe studs, glass beads and two rings, one of them of copper alloy and the other in gold and with an inscription that may be read as a personal name: $\operatorname{PAVL}(a)$. Another completely exceptional discovery was a small textile fragment, a piece of linen cloth (GUTIÉRREZ CUENCA et al. 2014), with numerous carbonised millet grains ${ }^{3}$ attached to it which may have been wrapped inside.

As in other contemporary burial caves located in Cantabria such as Las Penas and La Garma (HIERRO-GÁRATE 2011) unusual behaviours linked to the treatment of corpses have been detected. The destruction and/or burning of some human bones were the most stunning of them. Incomplete skulls, usually preserved in small fragments with evidences of burning, have been found in Riocueva. The skulls were crushed after excarnation and before burning took place. Also, some parts of the post-cranial skeletons show signs of fire, probably because they were beside the skulls when they were burnt. Burning occurred once the bones had already lost their flesh and fire temperatures ranged between $300^{\circ} \mathrm{C}$ and $600^{\circ} \mathrm{C}$. The range of colours exhibited by burned bones varying from light brown to white points to an irregular exposure to fire.

These practices are not related to ancient fu- nerary traditions, such as the cremation of corpses, which was a traditional practice from the Iron Age and early Roman times in the Iberian Peninsula. In the case of Riocueva, the burning of human remains was performed inside the cave but some time surely years- after the "burial". The anthropological study of the human remains has attested that bone was mostly dry when it was burnt, after natural defleshing. Besides, all the evidence seems to point to an attempt to destroy the body, or, better, a specific part of it, like the head. This probably occurred in a scenario of complex post-sepulchral practices, perhaps related to "necrophobia", the fear of the dead.

As it occurs with other burial caves from 6th8th centuries in the Iberian Peninsula, especially in Cantabria, some elements make this funerary context different from the "ordinary" contemporaneous cemeteries (GUTIÉRREZ CUENCA \& HIERRO GÁRATE, 2015): 1) the exclusive presence of young individuals, most of them under 35 years of age; 2 ) the collective nature of the deposits; 3 ) the discontinuous funerary use of the cave, beyond some decades in the best-case scenario; 4) the large number of elements associated with clothing and personal adornment accompanying the bodies; and 5) the absolutely unusual presence of everyday objects beside them. The identification of probably ritual or symbolic behaviours related to the dead, such as the burning of human remains, particularly the skulls, and grain contributes to make the difference sharper with respect to the contemporary necropolis. The choice of caves with difficult accesses is totally unsuited for human activities such as habitation, livestock shelterings, sanctuaries, and even water or dark earth procurement.

\subsection{Plant macro-remains}

In addition to these human remains, loose and crusted charred plant macro-remains have been recovered dispersed throughout the cave. A preliminary assessment of the non-woody plant remains from pinch/grab and dry-sieved samples revealed that the assemblage includes acorns (Quercus sp.) and seeds of flax (Linum usitatissimum), crucifers or mustard family (Brassicaceae) and foxtail millet (Setaria italica). These are plant remains which would have not been chosen as fuel due to their low calorific power, nor could have accidentally arrived within the fuel. On the one hand, both flax, foxtail millet and possibly the crucifers or mustards, would have been cultivated plants, and the effort of putting them into cultivation would have only been economically sensible if destined to uses such as food, oil or fibre extraction, among others. Only by-

\footnotetext{
${ }^{2}$ The anthropological study has been carried out by Silvia Carnicero Cáceres.

${ }^{3}$ A few loose grains detached from the cloth were initially identified in the "Lydia Zapata" Paleobotany Laboratory of the University of the Basque Country as Panicum miliaceum and as such appeared in the poster presented in 2012 in the colloquium Archaeology of farming and husbandry in Early Medieval Ages (5th$10^{\text {th }}$ centuries) under the title "Cereal consumption in early medieval Cantabria ( $7^{\text {th }}$ - 8th centuries AD): making the dead talk", P. Arias Cabal; E. Gutiérrez Cuenca; J.A. Hierro Gárate; I. López López-Dóriga. However, the examination of the grains attached to the cloth has allowed to establish the dominance of Setaria italica and it has been reported as thus since in subsequent publications (GUTIÉRREZ-CUENCA et al. 2014).
} 
products such as chaff, or products no longer fit for human consumption, such as germinated grains, would have been eventually discarded into fires. Even then, they would play a poor role as fuels, and would have been more likely used for foddering domestic animals. On the other hand, it is highly unlikely that acorns could have arrived as fuel or unintentionally as part of the fuel. It would only be so in thin branches brought to the site in a fresh state, as dry or deadwood rarely has nuts attached. The use of fresh thin branch wood as combustible is rather improbable (DIETSCH 2007), because it is less easily lit and requires more effort and time than dry or deadwood (Moskal Del Hoyo et al., 2010; THÉRY-PARISOT et al., 2010) which would have been plentiful in the immediate environment. Furthermore, the use of Quercus sp. branch as fuel is not supported by the wood charcoal analysis (see later, and Table 4).

The case of a crust of foxtail millet grains attached to a fragment of woven flax linen cloth (GUTIÉRREZ CUENCA et al. 2014) ${ }^{4}$ is particularly interesting (Fig. 2). On the one hand, it suggests the possibility of grains having been deposited within the cloth. On the other hand, it forms a consistent assemblage which can be used as a taphonomical

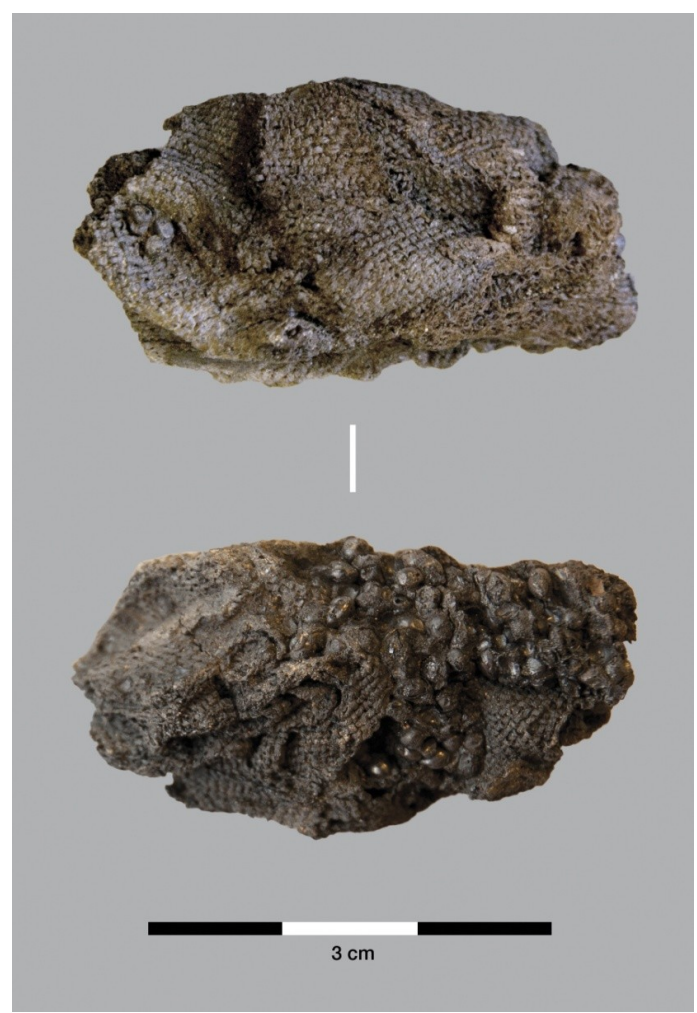

Fig. 2. Crust of foxtail millet grains and linen cloth recovered in test pit 2 .

Fig. 2. Amalgama de granos de mijo y tejido de lino recuperado en el sondeo 2 . proxy. The solidified protruded endosperm of the millet grains holds them together forming a crust, further adhered to the partially carbonised linen cloth. Grain protrusion is a phenomenon due to carbonisation at high temperatures (BRAADBAART 2008; MARKLE \& ROSCH 2008) which in the case of millets must have been between 250 and $300{ }^{\circ} \mathrm{C}$ for about $0.5 \mathrm{~h}$ (YANG 2011). Higher temperatures and higher exposure times would have distorted the grains so as to become unidentifiable. However, some of the glumes, which are usually destroyed at lower temperatures than grains (BOARDMAN \& JONES 1990) are still enclosing them. This combination of factors indicates an uneven, short and abrupt exposure to heat which has partially carbonised the cloth and preserved by carbonisation fragile elements such as chaff, whilst protrusion and solidification of the caryopses liquid endosperms has also occurred. This differential preservation could relate to differences in the distance to the fire (HUBBARD $\&$ ClaPHAM 1992), as the evidence in human bones also suggests. This is consistent with the interpretation of a single fire event, possibly in test pit 8 .

It is still difficult to reach a definite conclusion about the significance of the plant macro-remain evidence, since only an assessment of the major plant taxa has been carried out so far, and additional samples need to be examined, taphonomically analysed and fully quantified. However, in light of the current assessment, it is possible to suggest the intentional introduction into the cave of crop products (foxtail millet, flax and probably crucifers) and nuts gathered from the wild (acorns), all of them items of economic interest and possibly stored in bags. Their mere use as fuel is highly unlikely, as discussed above. Other possible explanations, such as the storage or even deliberate hide of products (e.g. BOUBY et al. 2005) which became later burnt, accidentally or not, cannot be fully excluded yet. However, it seems an unlikely possibility given the unfavourable conditions of the cave for storage (wet above ground, shallow underground) and the probable association, as confirmed by the radiocarbon dating results, to the deposit of human remains. Therefore, a symbolic use is more likely involved.

The symbolic interpretation of the assemblage is further supported by documentary evidence, since grain burning is a practice reflected in several penance books of the Middle Ages (FILOTAS 2005). This behaviour surely of preChristian origin, like most of magical and ritual practices condemned in those books (MCNEILL 1933; FILOTAS 2005; LÓPEZ-MAYÁN 2009), must have been relatively widespread, as it appears in penitentials from different European regions like England, Germany or Spain; and has received the ecclesiastical condemnation since Early Medieval times. In fact, the first mention appears in the Liber

${ }^{4}$ See previous note on the identification. 
Poenitentialis Theodori $(1,15.3)$, from the 7 th or 8th century, and it says as follows: "Qui ardere grana facit, ubi mortuus est homo pro sanitate viventium et domus, $V$ poenitea annos" ${ }^{5}$. The citations are repeated in almost every penitential. Another good example from the 11th century can be found in the Silos (Burgos, Spain) penance book, which is indeed the geographically closest to Cantabria. It reads thus: "Mulier, si grana arserit ubi mortuus est homo pro sanitate uibentium, I annum peniteat" $^{\prime 6}$ (Poenitentiale Silense, 198).

In addition to this plant macro-remain assemblage from Riocueva, grain burning has also been potentially identified in the cave of Las Penas, in Cantabria too, where many charred seeds of cereal, other crops and possible weeds where recovered beside the burned human remains (GUTIÉRREZ CUENCA et al. 2015) ${ }^{7}$. This is possibly the first identification of this obscure practice in the archaeological record of the Iberian Peninsula, dating from roughly the same time, the 7th-8th centuries, as the oldest written sources regarding it.

\section{MATERIAL AND METHODS}

Fragments of wood and wood charcoal were spread all over the site, together with the human bones and the archaeological objects. The archaeobotanical sampling strategy consisted in handpicked and bulk soil samples. Hand-picked samples were obtained upon excavation when charred plant material was observed and were aimed at its recovery without further need to process. Bulk soil samples have been processed either by dry-sieving or by flotation on a Syraf-type tank with a $0.25 \mathrm{~mm}$ mesh for the light fraction. The uncharred wood and char- coal remains from flotation samples have not been studied yet.

Fifty-one samples of charcoal and uncharred wood recovered by hand and by dry-sieving of bulk samples have been studied, and 230 fragments of charcoal $(n=201)$ and wood $(n=29)$ have been identified. The number of samples per test pit (following the spatial distribution inside the cave) is summarised as follows: test pit $8(\mathrm{~N}=4), 5(\mathrm{~N}=8), 1(\mathrm{~N}=2), 2$ $(\mathrm{N}=8), 7(\mathrm{~N}=21), 4(\mathrm{~N}=3), 4-\mathrm{H}(\mathrm{N}=1), 6(\mathrm{~N}=2)$ and 3 $(\mathrm{N}=2)$. Differences regarding the intra-site distribution of wood and charcoal inside the cave were recorded, charred and uncharred wood remains were recovered mostly in test pits 5 and 4, with the highest concentration at test pit 7 (Fig. 3). Our methodological approach started with the microscopic study, identifying taxonomically each fragment according to its specific anatomical patterns on the three sections of wood (cross, tangential and radial). These identifications were based on wood anatomy atlases and their identification keys (SCHWEINGRUBER 1990, GALE \& CUTLER 2000, HATHER 2000). In the genus Acer, two groups were distinguished based on the anatomical differences described by HATHER (2000: 128). The first group is defined by rays of 7 cells width and 70 cells high and included $A$. pseudoplatanus and $A$. platanoides. The second one is integrated by $A$. campestre, A. opalus and A. monspessulanum, with rays of 2-3 cells of width and up to 30 cells high.

Dendrological attributes were recorded from each fragment in tandem with botanical identification. If anatomical and morphological characteristics were identifiable, the part of the plant (i.e. trunk, twig, root, etc.) was registered (SCHWEINGRUBER et al. 2008). Tree-ring curvature was also evaluated

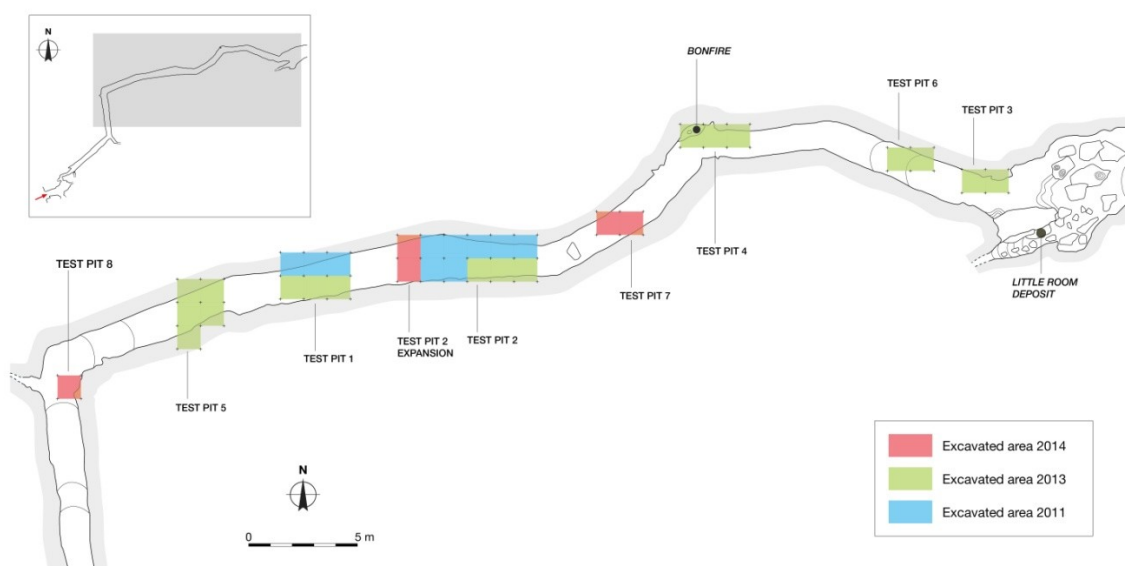

Fig. 3. Spatial distribution of test pits inside the cave. Archaeobotanical results are presented following the spatial distribution of test pits inside the cave.

Fig. 3. Distribución espacial de los sondeos en el interior de la gruta. Los resultados arqueobotánicos se presentan siguiendo la distribución espacial de los sondeos en el interior de la cueva.

\footnotetext{
5 "Whoever burns grain where there is a dead man, for the health of the living and of the house, should do penance for five years".

6 "Woman, if you burn grain where there is a dead man, for the health of the living, you should do penance during one year".

${ }^{7}$ An initial assessment of the charred plant macroremains was presented in the colloquium Archaeology of farming and husbandry in Early Medieval Ages (5th10th centuries) under the title "Cereal consumption in early medieval Cantabria (7th - 8th centuries AD): making the dead talk", P. Arias Cabal, E. Gutiérrez Cuenca, J.A. Hierro Gárate, I. López López-Dóriga).
} 
using qualitative categories: i.e. weak, moderate, strong and indeterminate (MARGUERIE \& HUNOT 2007). When the stem was preserved complete, its diameter was measured and if bark was present, the cutting season was also recorded (MARGUERIE \& HUNOT 2007). Early wood to late wood boundary is visible in all species whose marginal fibre tissue cells are flattened, in ring-porous species only the early wood contains the zone with large pores and in diffuse-porous species the early wood makes up almost the entire ring and only a very narrow zone with flat fibres can be considered as late wood (SCHWEINGRUBER 2007: 17). When both bark and pith were present, the number of annual rings was counted (MORGAN 1988).

Other features such as anatomical alterations have been also evaluated. Alterations associated with the combustion process were recorded, such as the presence of cracks -radial, tangential or arbitraryand the vitrification of tissues (THÉRY-PARISOT 2001; MARGUERIE \& HunOT 2007: BRAADVAART \& POOLE 2008). Anatomical alterations of wood, such as compartimentalisation and the presence of narrow rings, were also identified. The presence of wood biodeterioration markers was recorded to provide information about its state before burning. The identification of tunnels resulting from wood-boring insects or woodworm degradation has been linked to the combustion of drifted dead wood (MARGUERIE \& HUNOT 2007). The presence of white filaments in cross sections of vessels corresponds to fungal hyphae that penetrate into the dead or dying wood un- der aerobic conditions (MARGUERIE \& HUNOT 2007). The taphonomy of archaeobotanical assemblages can be approached through the study of fragmentation. Charcoal breakage is the result of both burning and post-depositional processes, fragmentation can occur either during combustion as an effect of temperature, burning conditions and the wood physical characters, and also after deposition as an effect of trampling, bioturbation, soil compression and sampling method (LANCELOTTI et al. 2010: 308; ChrZAZVEZ et al. 2014, 2011). The analytical protocol involved the measurement of the length of each charcoal fragment prior to identification (MARTíNSEIJO 2013) and recording the occurrence of erosion, identified by the presence of rounded corners (RODRÍGUEZ-ARIZA 1993; CARACUTA et al. 2012).

\section{RESULTS}

The following taxa have been identified in the charcoal assemblages: oak (including both Quercus sp. deciduous and Quercus sp.), hazel (Corylus avellana), beech (Fagus sylvatica), pine (Pinus sp. and Pinus tp. pinea/pinaster), shrubby Fabaceae, maple (Acer sp. including Acer gr. campestre and pseudoplatanus), ash (Fraxinus sp.), chestnut (Castanea sativa), oak/chestnut (Quercus sp./Castanea sativa), alder buckthorn (Frangula alnus), plums/cherries (Prunus sp., cf. Prunus sp.), Rosaceae/Maloideae, alder (Alnus sp.), buckthorn/mock privet (Rhamnus sp./Phyllirea sp.), strawberry tree (Arbutus unedo), ivy (Hedera helix) and elm (Ulmus sp.) (Table 3, Fig. 4).

Table 3. Results of the taxonomical charcoal analysis by test pit, organised reflecting their intra-site distribution.

Tabla 3. Resultados del análisis taxonómico antracológico por sondeo, ordenados de acuerdo a su distribución microespacial.

\begin{tabular}{|c|c|c|c|c|c|c|c|c|c|}
\hline & \multicolumn{9}{|c|}{ Test pit } \\
\hline Taxa & $\mathbf{8}$ & $\mathbf{5}$ & $\mathbf{1}$ & $\mathbf{2}$ & $\mathbf{7}$ & $\mathbf{4}$ & $\mathbf{4}-\mathbf{H}$ & $\mathbf{6}$ & $\mathbf{3}$ \\
\hline Quercus sp. deciduous & 3 & 1 & 4 & 13 & 16 & 6 & 5 & 3 & \\
\hline Corylus avellana & 1 & 8 & 4 & 5 & 16 & 3 & & 1 & 8 \\
\hline Fagus sylvatica & & 16 & 1 & 2 & 5 & 7 & 4 & 5 & 7 \\
\hline Fabaceae & 1 & & & 1 & & 4 & & & 1 \\
\hline Pinus tp. pinea/pinaster & & 1 & & 1 & 3 & & & & \\
\hline Fraxinus sp. & & & 4 & & 1 & 1 & & & \\
\hline Quercus sp./C. sativa & & & 1 & & 8 & & & & \\
\hline Acer gr. campestre & & 3 & 2 & & & & & & \\
\hline Quercus sp. & & & & 2 & & & & & 2 \\
\hline Frangula alnus & 1 & & & & & & & 1 & \\
\hline Rosaceae/Maloideae & & 1 & 1 & & & & & & \\
\hline Alnus sp. & & & & 1 & 1 & & & & \\
\hline Castanea sativa & & & & & 3 & & & & \\
\hline Rhamnus sp./Phyllirea sp. & & & & & & 2 & & & \\
\hline Pinus sp. & & & & & 1 & & & & \\
\hline Acer gr. pseudoplatanus & & & & & 1 & & & & \\
\hline Prunus sp. & & & & & & 1 & & & \\
\hline cf. Prunus sp. & & & & & & 1 & & & \\
\hline Arbutus unedo & & & & & & & & & 1 \\
\hline Hedera helix & & & & & & & & & 1 \\
\hline Ulmus sp. & & & & & & & & & 1 \\
\hline Dicotyledonous & $\mathbf{6}$ & $\mathbf{3 0}$ & $\mathbf{1 8}$ & $\mathbf{2 6}$ & $\mathbf{5 5}$ & $\mathbf{2 5}$ & $\mathbf{9}$ & $\mathbf{1 0}$ & $\mathbf{2 2}$ \\
\hline
\end{tabular}



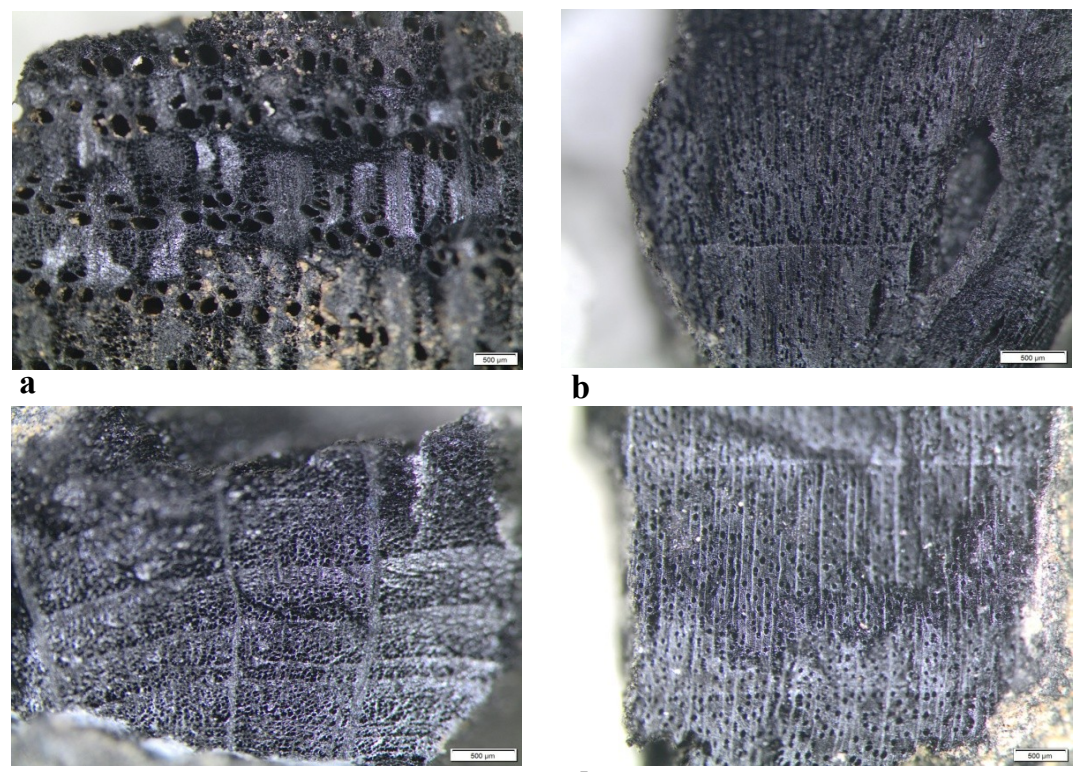

c

\section{b}

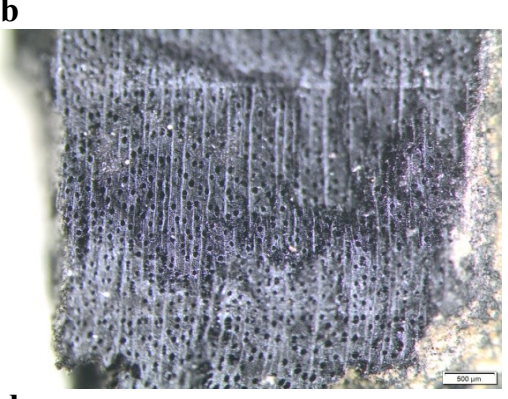

Fig. 4. Charcoal. a) Oak (Quercus sp. deciduous) from test pit 8; b) hazel (Corylus avellana), this fragment presents radial cracks; c) beech (Fagus sylvatica) and d) Acer $\mathrm{sp}$. from test pit 3 .

Fig. 4. Carbón. a) Roble (Quercus sp. deciduous) del sondeo 8; b) avellano (Corylus avellana), este fragmento presenta grietas radiales; c) haya (Fagus sylvatica); d) Acer sp. del sondeo 3.

The anatomical analysis revealed that knot wood fragments were only occasionally present, with one fragment of Fagus sylvatica in test pit 5, two of Quercus sp. in test pit 2 and one of Corylus avellana in test pit 3 . Twigs were identified in seven of the test pits. Their total number was 34, most of which corresponded to hazel and the remainder to diverse taxa: Fabaceae, Fagus sylvatica, Rosaceae/Maloideae, Alnus sp., Quercus sp. deciduous, Quercus sp./Castanea sativa, Fraxinus sp., Prunus sp., Frangula alnus and Arbutus unedo (Table 4).

Table 4. Twig fragments in charcoal assemblages by test pit.

Tabla 4. Fragmentos de ramas en los conjuntos de carbones por sondeo de procedencia.

\begin{tabular}{|c|c|c|c|c|c|c|c|}
\hline & \multicolumn{7}{|c|}{ Test pit } \\
\hline Taxa & $\mathbf{8}$ & $\mathbf{1}$ & $\mathbf{2}$ & $\mathbf{7}$ & $\mathbf{4}$ & $\mathbf{6}$ & $\mathbf{3}$ \\
\hline Corylus avellana & 1 & & 3 & 15 & 2 & & \\
\hline Fabaceae & 1 & & & & 2 & & \\
\hline Fagus sylvatica & & & 1 & & & & 1 \\
\hline Rosaceae/Maloideae & & 1 & & & & & \\
\hline Alnus sp. & & & & 1 & & & \\
\hline Quercus sp. deciduous & & & & 1 & & & \\
\hline Quercus sp./C. sativa & & & & 1 & & & \\
\hline Fraxinus sp. & & & & & 1 & & \\
\hline Prunus sp. & & & & & 1 & & \\
\hline Frangula alnus & & & & & & 1 & \\
\hline Arbutus unedo & & & & & & & 1 \\
\hline TOTAL & 2 & 1 & 4 & 18 & 6 & 1 & 2 \\
\hline
\end{tabular}

Most of the twigs were gathered in test pit 7 , where eighteen twigs were identified. In this assemblage, the diameters of the branches ranged from 0.8 to $1.3 \mathrm{~cm}$, corresponding to ages between two and six years old (Table 5). The fragments with bark allowed to establish the season of plant death, which in 10 out of 11 cases was consistent with late wood: Corylus avellana $(\mathrm{N}=6)$, Alnus sp. $(\mathrm{N}=1)$, Castanea sativa $(\mathrm{N}=1)$, Pinus sp. $(\mathrm{N}=1)$ and Quercus sp. deciduous $(\mathrm{N}=1)$. Only in one fragment of Corylus avellana the season of plant death was early wood.

Anatomical alterations related to the growing conditions of the tree (narrow rings, compartmentalisation and tension wood) and to wood biodeterioration (xylophagous galleries, hyphae) were identified (Table 6). The presence of these alterations is restricted in all the samples considered in 
this study. Alterations related to the combustion process like the presence of cracks or vitrification of the tissues, were registered, but the results were inconclusive.

The largest pieces of charcoal were recovered from test pits 2, 7 and 4 (Fig. 5). In these assemblages, charcoal fragments up to $1 \mathrm{~cm}$ predomi- nate. Charcoal was associated to the higher concentration of burned bones in test pits 2 and 7 .

Charcoal fragments with rounded corners concentrate in test pit 1, 7 and 3 (Fig. 6) and the highest percentage of eroded fragments was identified in the latter.

Table 5. Number of annual tree-rings in charcoal fragments recovered from test pit 7 .

Tabla 5. Número de anillos anuales en fragmentos de carbón recogidos en el sondeo 7.

\begin{tabular}{|c|c|c|c|c|c|}
\hline Test pit $\mathbf{7}$ & \multicolumn{5}{|c|}{ Number of tree-rings } \\
\hline Taxa & $\mathbf{2}$ & $\mathbf{3}$ & $\mathbf{4}$ & $\mathbf{5}$ & $\mathbf{6}$ \\
\hline Corylus avellana & 1 & 2 & 1 & 1 & 1 \\
\hline Quercus sp. deciduous & & & & 1 & \\
\hline Alnus sp. & & & 1 & & \\
\hline
\end{tabular}

Table 6. Anatomical alterations related to the tree growing conditions (narrow rings, compartmentalisation and tension wood) and to wood biodeterioration (xylophagous' galleries, hyphae)

Tabla 6. Alteraciones anatómicas relacionadas con las condiciones de crecimiento del árbol (anillos estrechos, compartimentalización y madera de tensión) y con el biodeterioro de la madera

\begin{tabular}{|c|c|c|c|c|c|c|c|c|}
\hline \multirow[b]{2}{*}{ Alterations } & \multicolumn{8}{|c|}{ Test pit } \\
\hline & 8 & 5 & 1 & 2 & 7 & 4 & 6 & 3 \\
\hline Narrow rings & & & & & 1 & 3 & & \\
\hline Compartmentalisation & & 1 & & & & & & \\
\hline Tension wood & & & & 1 & & & & \\
\hline Xylophages galleries & & & & 1 & 3 & & & 1 \\
\hline Hyphae & & & & & & & & 1 \\
\hline
\end{tabular}

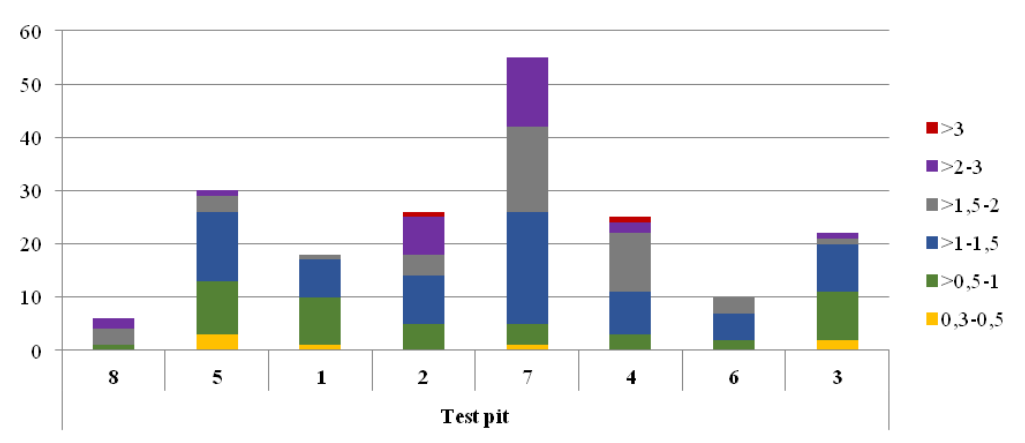

Fig. 5. Size (in cm.) of charcoal fragments in relation to their test pit of provenance.

Fig. 5. Tamaño (en $\mathrm{cm}$.) de los fragmentos de carbón en relación con su sondeo de procedencia.

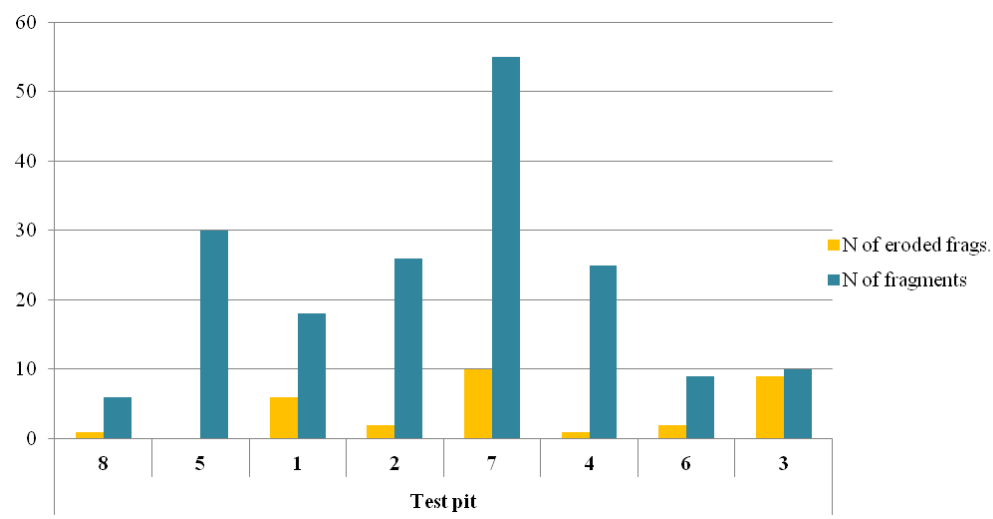

Fig. 6. Number of charcoal fragments with rounded corners owing to erosion.

Fig. 6. Número de fragmentos de carbón con esquinas redondeadas indicadoras de la existencia de erosión. 
Taxonomical diversity was notably lower in the uncharred wood samples than in the charcoal assemblages. Wood remains were less frequently preserved than charcoal and were recovered only from test pits 8, 5, 2, 7 and 3. As in the case of charcoal, most of the wood pieces were gathered in test pit 7. This fact led us to hypothesize that these un- charred wood remains could be related to mortuary treatments developed in the cave. Quercus sp. deciduous was the best represented taxon with 22 noncarbonised wood fragments, the remainder of the taxa were only occasionally present: Corylus avellana, Pinus sp., Quercus/Castanea, Rhamnus sp./ Phyllirea sp. and dicot (Table 7, Fig. 7).

Table 7. Results of the uncharred wood taxonomical analysis by test pit, organised according to their intra-site distribution.

Tabla 7. Resultados del análisis xilológico por sondeos de procedencia, organizados de acuerdo con su distribución microespacial.

\begin{tabular}{|c|c|c|c|c|c|}
\hline & \multicolumn{5}{|c|}{ Test pit } \\
\hline Taxa & $\mathbf{8}$ & $\mathbf{5}$ & $\mathbf{2}$ & $\mathbf{7}$ & $\mathbf{3}$ \\
\hline Quercus sp. deciduous & 3 & 3 & 6 & 10 & 1 \\
\hline Corylus avellana & & & 1 & & \\
\hline Pinus tp. pinea/pinaster & & 1 & & 1 & \\
\hline Castanea sativa & & & & & 1 \\
\hline Rhamnus sp./Phyllirea sp. & & & & 1 & \\
\hline Dicot & & 1 & & & \\
\hline TOTAL & $\mathbf{3}$ & $\mathbf{5}$ & $\mathbf{7}$ & $\mathbf{1 2}$ & $\mathbf{2}$ \\
\hline
\end{tabular}

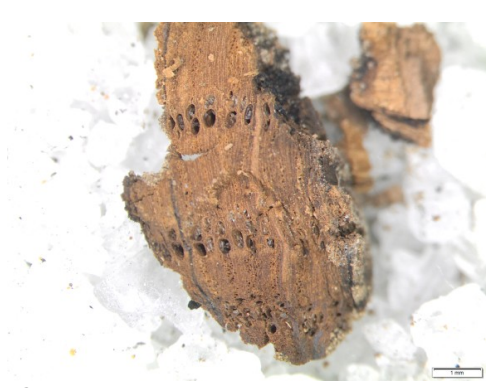

a

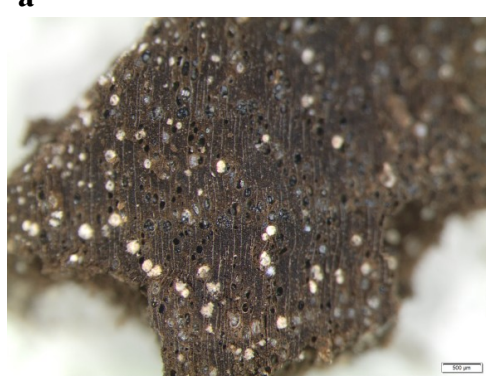

b
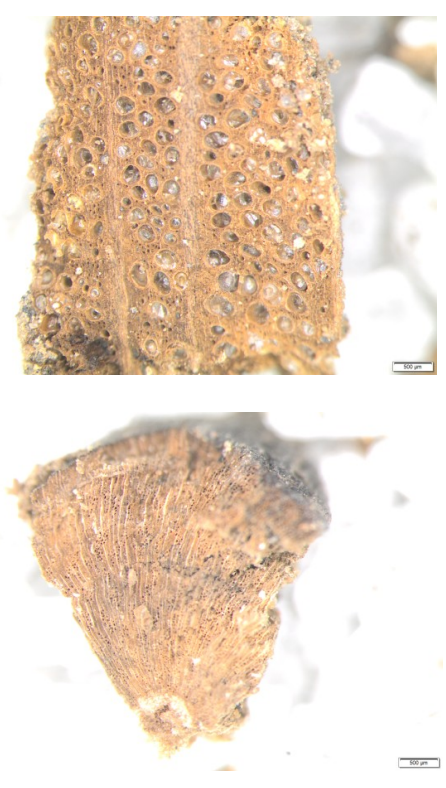

Fig. 7. Uncharred wood. Oak (Quercus sp. deciduous): a) from test pit 5 and b) from test pit 7, this fragment presents narrow tree rings; c) chestnut (Castanea sativa) from test pit 3; buckthorn/mock privet (Rhamnus $\mathrm{sp}$./Phyllirea $\mathrm{sp}$.) from test pit 7.

Fig. 7. Madera no carbonizada. Roble (Quercus sp. deciduous): a) del sondeo $5 \mathrm{y} \mathrm{b}$ ) del sondeo 7, este fragmento presenta una alteración en el ritmo de crecimiento del anillo anual; c) castaño (Castanea sativa) del sondeo 3; espino/labiérnago (Rhamnus sp./Phyllirea sp.) del sondeo 7.

Most of the uncharred wood remains belong to trunks or big branches (Table 8) and only sporadically twigs were identified: Quercus sp. deciduous (test pit 5) and Rhamnus sp./ Phyllirea sp. (test pit 7). Tree-ring curvatures were weak and moderate in 23 cases. Narrow rings were observed in two fragments of Quercus sp. deciduous recovered in test pit 7 (Fig. $6 \mathrm{~b})$. Hyphae were identified in two fragments of Quercus sp. deciduous in test pit 7 and xylo- phagous' galleries in one fragment of Quercus sp. deciduous in test pit 2.

Size of non-carbonised wood pieces ranged from 1.3 to $8 \mathrm{~cm}$. The biggest fragments were recovered in test pits 2 and 7 (Fig. 8).

Rounded corners were identified in 9 noncarbonised wood pieces, in test pits $7(\mathrm{~N}=4), 5$ $(\mathrm{N}=2), 3(\mathrm{~N}=2)$ and $2(\mathrm{~N}=1)$, corresponding to Quercus sp. deciduous $(\mathrm{N}=6)$, Pinus tp. pinea/ pinaster $(\mathrm{N}=2)$ and Castanea sativa $(\mathrm{N}=1)$. 
Table 8. Plant parts identified in uncharred wood fragments by test pit. Tabla 8. Identificación de las partes de la planta en fragmentos de madera no carbonizada por sondeo.

\begin{tabular}{|c|c|c|c|c|c|}
\hline & \multicolumn{5}{|c|}{ Test pit } \\
\hline Plant part & $\mathbf{8}$ & $\mathbf{5}$ & $\mathbf{2}$ & $\mathbf{7}$ & $\mathbf{3}$ \\
\hline Trunk & 2 & 2 & 4 & 11 & 1 \\
\hline Twig & & 1 & & 1 & \\
\hline Stem & 1 & 2 & 3 & & 1 \\
\hline TOTAL & $\mathbf{3}$ & $\mathbf{5}$ & $\mathbf{7}$ & $\mathbf{1 2}$ & $\mathbf{2}$ \\
\hline
\end{tabular}

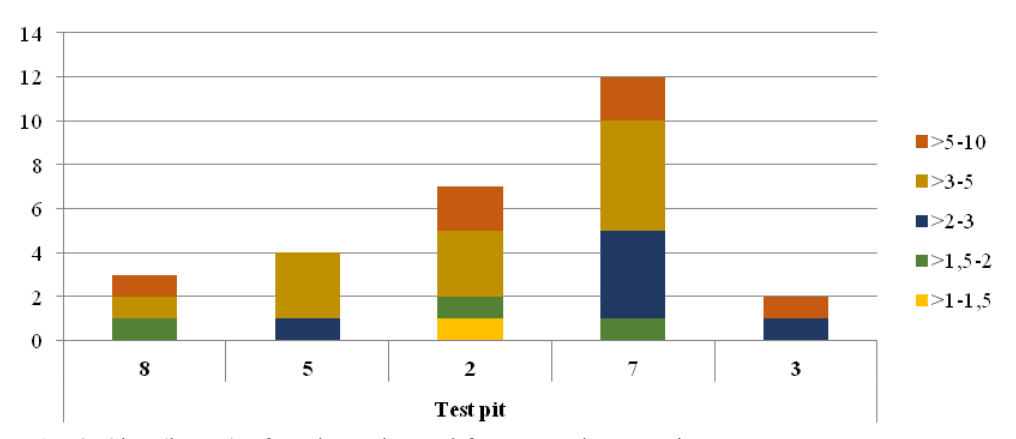

Fig. 8. Size (in $\mathrm{cm}$ ) of uncharred wood fragments by test pit.

Fig. 8. Tamaño $(\mathrm{en} \mathrm{cm})$ de los fragmentos de madera no carbonizada por sondeo de procedencia.

\section{DISCUSSION}

Assemblages of charred plant macro-remains, charcoal and uncharred wood recovered in Riocueva were intentionally introduced in the cave for different purposes. This preliminary study provides clues about their possible use. The plant evidence has been only partially assessed yet: a preliminary assessment of dominant plant taxa has been carried out in a selection of macro-remain samples and charcoal and wood recovered by flotation have not been studied yet, so the number of taxa and their presence and percentage are only illustrative. The possibly earliest evidence of activity in the cave is a fireplace identified in test pit $4 \mathrm{H}$. The cave wall still bears the marks of the flames and the heat. A taxonomically unidentified charcoal fragment from this feature was dated between the 2nd and the 4th centuries AD (Table 1). Since only two long-lived taxa, Quercus sp. deciduous and Fagus sylvatica, were identified in the charcoal assemblage from this feature (Table 3), it is possible that an old-wood effect is occurring. Therefore, the possibility that the fireplace may be contemporaneous to the other more recent activities in the cave more reliably radiocarbon dated with short-lived samples can not be excluded. It is even possible that the fire was lighted in much more recent times using the old wood preserved uncharred in the cave.

It is our hypothesis that the remainder of the charcoal and wood assemblages were probably related to the sepulchral use of the cave. The manipulation of human bones inside the cave involved the use of wood resources in several stages of the process: to transport the human remains, to provide light inside the cave and finally to burn the bones and other items, such as textiles, cereals and acorns. The preservation of non-carbonised wood is probably related to the high humidity and stable temperature conditions inside the cave. The presence of wood has been previously reported in other caves located in this area (e.g. SERNA GANCEDO et al. 1994; GUTIÉRREZ-CUENCA \& HiERRO-GÁRATE 2010.). Uncharred wood remains are less frequent than charcoal and Quercus sp. deciduous is the most ubiquitous taxon. All the species identified in the non-carbonised wood assemblages have been also identified in the charcoal samples. The interpretation of these non-carbonised wood remains is not straightforward, but some of them could have been part of the implements used to transport the human bones, and others could be part of nonburnt firewood or lighting artefacts such as torches.

In the first bend of the Galeria del Campamento, namely in the eastern end of test pit 2 and test pit 8 , the cave walls preserved evidences of fire damage, indicating where fires were probably set. The highest number of charcoal and wood pieces and the highest number of archaeological remains -including human bones, pottery, metal objects and carpological remains- have been found in the area comprised by test pits 5, 1, 2, 7 and 4 . Test pits 2, 7 and 4 produced the less fragmented charcoal assemblages (Fig. 5) and the bigger pieces of wood (Fig. 8). This could pinpoint the occurrence of the funerary practices involving the use of fire in this area. Ubiquitous taxa represented in the charred wood assemblages throughout the cave were Quercus sp. deciduous, Corylus avellana and Fagus sylvatica (Table 3), indicating that these 
three species were probably the main fuel for the firing of skulls and bones. Quercus spp. and Fagus sylvatica have been reported as the preferred wood for fuel in anthracological analysis from Medieval contexts from Northern Iberia (RUIZ-ALONSO 2014) and in ethnobotanical studies (PARDO DE SANTAYANA 2003; ZAPATA \& PEÑA-CHOCARRO 2003). Fagus sylvatica could be burnt even green, and provides big flames but it is a short-lasting firewood, while Quercus spp. is a long-lasting fuel that produces embers and provides high calorific values, although it requires good ventilation to maintain a regular heat (GALE \& CUTLER 2000; LÓPEZ 2002; PARDO DE SANTAYANA 2003; ZAPATA \& PEÑA-CHOCARRO 2003). Corylus avellana wood was also appreciated for charcoal production and as occasional firewood, although this shrub has a lot of uses in traditional communities including manufactures, animal foddering and human consumption, medicinal applications, etc. (PARDO DE SANTAYANA 2003). Sticks of Corylus avellana have been used in the past to repel evil (GALE \& CUTLER 2000) and they are also present in some Early Medieval graves of northern Europe, perhaps with a prophylactic function (HoLLOWAY 2008). In the Lower Gallery of La Garma, another burial site from the 7 th- 8 th centuries $\mathrm{AD}$, charcoal remains of young branches of hazel wood have been also identified. They were probably gathered in the vicinity of the cave, and seem to have been used for lighting purposes, such as in torches and small hearths (ARIAS et al. in press).

The wide botanic diversity of charcoal assemblages -considering that only hand-picked and dry sieved samples have been studied - could indicate a selection of firewood complemented by a random gathering strategy. But the spatial distribution of the minor taxa is restricted to specific test pits. Pinus sp. charcoal and wood concentrate in the area comprised by test pits 5, 1, 2 and 7 (Table 3 and 7). Other three taxa (Fraxinus sp., Acer spp. and Pinus spp.) showed a restricted spatial distribution in test pits 5 and 4 (Table 3). The assemblage from test pit 3 is rather different to the other pits regarding its taxonomic composition. In addition, the taxa identified only occasionally are not necessarily good fuels -e.g. Alnus sp. burns badly and produces smoke - and in most of the cases only small branches have been identified. Both facts could support the hypothesis of a random gathering strategy of light fuel for use in fire starting. This could be also the case of Pinus spp., which provides a soft wood that burns very quickly, being usually used to light fires (ZAPATA \& PEÑA-CHOCARRO 2003) and is appreciated for torches inside mines and caves (SEGURA \& TORRES 2009). Additionally, the presence of certain taxa could also be explained as being part of the rite and could be related to their symbolic meaning. Protective properties have been reported for millet (DE CleENE \& LeJeune 2003b: 126), flax (DE CleENe \& LeJeune 2003b: 236-237), hazel (De Cleene \& LeJeune 2003a: 312-313) and alder wood (DE CLEENE \& LEJEUnE 2003a: 74). Even during the Post-Medieval period millet, flax and mustard seeds were deposited inside the tombs or in the cemeteries to hinder the revenants (BARBER 1988: 49).

The presence of beech wood used as fuel is especially interesting in a paleoenvironmental sense, since it is a species currently absent in the immediate environment and can only be found some kilometres to the South, at higher grounds. If, as inferred, the wood introduced in the cave was gathered in the near environment, the distribution of beech trees would have been different in Early Medieval times. However, firewood could also have been gathered in the surroundings of occupation sites.

\section{CONCLUSION}

Archaeobotanical assemblages recovered from Riocueva have provided a glimpse into funerary and post-sepulchral practices developed between the 7th and 8th centuries AD involving the destruction and burning of bones and cereal grains, other crops and economic nuts. Wood made part of this funerary rite as firewood for burning human bones after defleshing, possibly as torches for lighting and even as wooden objects. Charcoal analysis has highlighted the important role played by three taxa: Quercus sp. deciduous, Corylus avellana and Fagus sylvatica, and the random gathering of other species, probably for use as fire starters. The spatial distribution of charcoal taxa and its taphonomical markers -fragmentation and erosion - has also provided clues about the formation processes of the archaeological record and the funerary and post-sepulchral activities inside the cave. In addition, this work is a first approach to the palaeoenvironment of the cave during the 7 th8 th centuries.

\section{REFERENCES}

Arias, P.; OnTAÑón, R.; GutiérRez CUENCA, E.; Hierro, J. A.; EtXeberria, F.; Herrasti, L. \& UzQuiano, P. i. p. Hidden in the depths, far from the people. The funerary context in the Lower Gallery at $\mathrm{La}$ Garma and the use of natural caves as burial places in early medieval Cantabria (Northern Spain). In: A Breivik and M. Dowd (Eds.): Cave rituals in medieval Europe (400-1200 AD). London.

BARBER, P. 1988. Vampires, burial, and death: folklore and reality. New Haven, Yale University Press.

BoArdman, S. \& Jones, G. E. M. 1990. Experiments on the effects of charring on cereal plant components. Journal of Archaeological Science, 17: 1-11.

Bouby, L.; FAGES, G. \& TrefForT, J. 2005 Food storage in two Late Bronze Age caves of Southern France: palaeoethnobotanical and social implications. Vegetation History and Archaeobotany, 14: 313-328. 
BRAADBAART, F. 2008. Carbonisation and morphological changes in modern dehusked and husked Triticum dicoccum and Triticum aestivum grains. Vegetation History and Archaeobotany, 17: 155-166.

BraAdBAart, F. \& PoOle, I. 2008. Morphological, chemical and physical changes during charcoalification of wood and its relevance to archaeological contexts. Journal of Archaeological Science, 35: 2434-2445.

Caracuta, V.; Fiorentino, G.; Turchiano, M. \& Volpe, G. 2012. Processi di formazione di due discariche altomedievali nel sito di Faragola. Il contributo dell'analisi archeobotanica. European Journal of Post-Classical Archaeology, 2: 225-246.

Chrzazvez, J.; ThÉry-Parisot, I.; Fiorucci, G.; Terral, J. -F. \& THIBAUT, B. 2014. Impact of post-depositional processes on charcoal fragmentation and archaeobotanical implications: experimental approach combining charcoal analysis and biomechanics. Journal of Archaeological Science, 44: 30-42.

De Cleeene, M. \& LeJeune, M.C. 2003a. Compendium of Symbolic and Ritual Plants in Europe. Vol. I. Trees \& Shrubs. Ghent, Man \& Culture Publishers.

De Cleeene, M. \& LeJeune, M.C. 2003b. Compendium of Symbolic and Ritual Plants in Europe. Vol. II. Herbs. Ghent, Man \& Culture Publishers.

DIETSCH, M.F. 2007. L'utilisation des plantes sauvages au Néolitique dans le nord-ouest de la France: témoignages carpologiques. In: M. Besse (Ed.), Sociétés néolitiques. Des faits archéologoques aux fonctionnements socio-économiques. Lausane, Cercle vaudois d'archéologie: 127-136.

FILOTAS, B. 2005. Pagan survivals, superstitions and popular cultures in early medieval pastoral literature. Toronto: Pontifical Institute of Mediaeval Studies.

GALE, R. \& Cutler, D. 2000. Plants in archaeology. Identification manual of vegetative plant materials used in Europe and the southern Mediterranean to $c$. 1500. Kew, Westbury and Royal Botanic Gardens.

Gutiérrez-CuencA， E. \& Hierro-GÁrate, J.A. 2010. Instrumentos relacionados con la actividad textil de época tardoantigua y altomedieval en Cantabria. Munibe, 61: 261-288.

Gutiérrez-CuencA, E. \& Hierro-GÁrate, J.A. 2010-12. Nuevas evidencias sobre el uso de las cuevas de Cantabria durante la Tardoantigüedad y la Alta Edad Media. Primeros resultados del Proyecto Mauranus. Sautuola, XVI-XVII: 263-280.

Gutiérrez-CuencA, E. \& Hierro-GÁrate, J.A. 2014. Proyecto Mauranus 2011. Intervención arqueológica en la cueva de Riocueva (Entrambasaguas). In: G. Sanz Palomera (Ed.), Actuaciones arqueológicas en Cantabria (2004-2011). Santander, Gobierno de Cantabria: 224-231.

GutiÉRrez-CuencA, E. \& Hierro-Gárate, J.A. 2015. Necrópolis y cuevas. Caracterización del registro funerario de los siglos VI-VIII en Cantabria. In: J.A. Quirós Castillo, S. Castellanos, (Eds.), Identidad y etnicidad en Hispania. Propuestas teóricas y cultura material en los siglos V-VIII. Vitoria, UPV/ EHU: 201-219.

GutiérREZ-CuEnCA， E. \& Hierro-GÁrate, J.A., 2016. Desenterrando a los últimos visigodos. Actuaciones arqueológicas en Riocueva (2010-2014), In: Cantabria, nuevas evidencias arqueológicas. Santander, ADIC-Los Cántabros: 155-185.
Gutiérrez-Cuenca, E.; Hierro-Gárate, J. A. \& Alfaro GINER, C. 2014. Restos textiles de la cueva de Riocueva, Hoznayo (Entrambasaguas, Cantabria). In: C. Alfaro, M. Tellenbach \& J. Ortiz (Coord.), Production and trade of textiles and dyes in the Roman Empire and neighbouring regions: Actas del IV Symposium Internacional sobre Textiles y Tintes del Mediterráneo en el mundo antiguo. Universitat de València, Valencia: 73-81.

HATHER, J.G. 2000. The identification of the Northern European Woods. A Guide for archaeologists and conservators. London, Archetype Publications.

Hierro-GÁrate, J. A. 2002. Arqueología de la Tardoantigüedad en Cantabria: yacimientos y hallazgos en cueva. Nivel Cero, 10: 113-128.

Hierro-GÁrate, J.A. 2011. La utilización sepulcral de las cuevas en época visigoda: los casos de Las Penas, La Garma y El Portillo del Arenal (Cantabria). Munibe, 62: 351-402.

Holloway, J. 2008. Charcoal burial: a minority burial rite in Early Medieval Europe. In: E.M. Murphy (Ed.), Deviant burial in the archaeological record. Oxford, Oxbow Books: 131-147.

HubBard, R.N.L.B. \& Clapham, A.R. 1992. Quantifying macroscopic plant remains. Review of $\mathrm{Pa}$ laeobotany and Palynology, 73: 117-132.

Lancelotti, C.; Madella, M.; Ajithprasad, P. \& Petrie, C.A. 2010. Temperature, compression and fragmentation: an experimental analysis to assess the impact of taphonomic processes on charcoal preservation. Archaeological and Anthropological Science, 2 (4) 307-320.

LÓPEZ-MAYÁn NAVARreTE, M. 2009. Aproximación histórica a un penitencial del final de la Alta Edad Media: el Corrector et Medicus de Burcardo de Worms. Rudesindus, 5: 103-134.

Marguerie, D. \& HunOt, J.Y., 2007. Charcoal analysis and dendrology: data from archaeological sites in north-western France. Journal of Archaeological Science, 34,:1417-1433.

MÄRKLE, T. \& Rosch, M. 2008. Experiments on the effects of carbonization on some cultivated plant seeds, Vegetation History and Archaeobotany, 17: 257-263.

MARTín-SeiJo, M. 2013. A xestión do bosque e do monte dende a Idade do Ferro a época romana no noroeste da península Ibérica: consumo de combustibles e produción de manufacturas en madeira. $\mathrm{PhD}$ Thesis. University of Santiago de Compostela.

MCNEILL, J. T. 1933. Folk-paganism in the penitentials. The Journal of Religion, 13 (4): 450-466.

MORGAN, R., 1988. The case for wattling - what tree-ring studies could reveal. In: P. Murphy \& C. French (Ed.), The Exploitation of Wetlands, Symposia of the Association for Environmental Archaeology, 7. Oxford, BAR British Series 186: 77-91.

Morlote, J.M.; MuÑoz, E.; SeRnA, A. \& VAlle, A. 1996. Las cuevas sepulcrales de la Edad del Hierro en Cantabria. La arqueología de los Cántabros. In: Actas de la I Reunión sobre la Edad del Hierro en Cantabria. Santander, Fundación Marcelino Botín: 195-279.

Moskal del Hoyo, M.; Wachowiak, M. \& Blanchette, R.A. 2010. Preservation of fungi in archaeologica charcoal. Journal of Archaeological Science, 37: 2106-2116. 
Fires in the dark. Wood and charcoal analysis of the Early Medieval funerary deposits in the cave of Riocueva (Cantabria,

PARDO DE SANTAYANA, M. 2003. Las plantas en la cultura tradicional de la antigua Merindad de Campoo. $\mathrm{PhD}$ Thesis, Universidad Autónoma de Madrid.

PEÑIL, J. \& RUIZ, F. 1971. Reseña arqueológica de Recueva. Cuadernos de Espeleología, 5-6: 129-133.

REIMER, P.J.; BARD, E.; BAYLISS, A.; BECK, J.W.; BLACKWell, P.G.; RAMSEY, C.B.; BuCK, C.E.; CHENG, H.; EdWARdS, R.L.; FrIEDRICH, M.; GROOTES, P.M.; GuIlderson, T.P.; Haflidason, H.; HAJDAS, I.; Hatté, Ch.; HeAton, T.J.; HofFManN, D.L.; HogG, A.G.; Hughen, K.A.; KaISER, K.F.; Kromer, B.; Manning, S.W.; NiU, M.; ReIMER, R.W.; RICHARDS, D.A.; SCOTT, E.M.; SOUTHON, J.R.; STAFF, R.A.; TURNEY, C.S.M. \& VAN DER Plicht, J. 2013. IntCal13 and Marine13 radiocarbon age calibration curves $0-50,000$ years cal BP Radiocarbon, 55 (4): 1869-1887.

RoDRÍGUEZ-ARIZA, M.O. 1993. Los procesos de formación y transformación del registro arqueológico en los estudios antracológicos. In: F. Burillo (Ed.) Arqueología Espacial, 16-17: 371-390.

RuIZ-Alonso, M. 2014. Evolución y explotación de los recursos vegetales desde el Tardiglaciar en la vertiente mediterránea del País Vasco: datos antracológicos. PhD Thesis, UPV/EHU.

SCHWEINGRUBER, F.H. 1990. Anatomy of European Woods. An atlas for the identification of European trees, shrubs and dwarf shrubs. Stutgart, Paul Haupt.

SCHWEINGRUBER, F.H.; BÖRNER, A. \& SCHUlze, E.D. 2008. Atlas of Woody Plant Stems. Evolution, Structure and Environmental Modifications. Berlin, Springer Berlag.
SEgurA, S. \& TORRES, J. 2009. Historia de las plantas en el mundo antiguo. Madrid, CSIC.

Serna Gancedo, A.; Malpelo García, B.; MuÑoz FERnÁNDEZ, E.; Bohigas RoldÁn, R.; SMIth, P \& García Alonso, M. 1994. La cueva del Aspio (Ruesga, Cantabria): Avance al estudio del yacimiento. In: J.A. Lasheras (Ed.), Homenaje al Dr. Joaquín González Echegaray. Madrid, Ministerio de Cultura: 369-396.

THERY-PARISOT, I. 2001. Économie des combustibles au Paléolithique: Expérimentation, taphonomie, anthracologie. Paris, CNRS.

ThÉRY-PARISOT, I.; ChABAL, L. \& ChrZAVZEZ, J. 2010 Anthracology and taphonomy, from wood gathering to charcoal analysis. A review of the taphonomic processes modifying charcoal assemblages, in archaeological contexts. Palaeogeography, palaeoclimatology, palaeoecology, 291 (1): 142-153.

YANG, Q.; LI, X.; ZHOU, X.; ZHAO, K.; JI, M. \& SUN, N. 2011. Investigation of the ultrastructural characteristics of foxtail and broomcorn millet during carbonization and its application in archaeobotany. Chinese Science Bulletin, 56 (14): 1495-1502.

ZAPATA, L. \& PEÑA-ChOCARro, L. 2003. Uso y gestión de bosque en la Euskal Herria atlántica: aprovechamiento tradicional de los recursos forestales en Encartaciones y Gorbea. Zainak, 22: 155-169. 